\title{
A narrativa mediada e a permanência da tradição: percurso de um anti-herói brasileiro Luiz Gonzaga Motta*
}

\section{Introdução}

O herói é o mito mais antigo, mais comum e mais conhecido de toda a humanidade porque tem forte poder de sedução e importância psicológica profunda. Guarda um enredo universal, prodigiosamente recorrente: nascimento humilde, busca incessante, tentações de vários tipos, provas de sua força física ou moral, falibilidade frente a essas tentações, ascensão rápida à notoriedade, declínio por traição e, finalmente, morte e ascensão. A psicanálise mostrou que cada fase desse ciclo reflete estágios da evolução da personalidade humana, de sua iniciação na busca de uma diferenciação e autonomia ou totalidade do ser (Henderson, 1964).

O autor mais citado sobre o ciclo do herói, J. Campbell (1997), chama esse percurso do herói de monomito, forma recorrente na literatura e mitologia. Sua universalidade, diz ele, é produto da psique humana: o inconsciente envia permanentemente à mente as fantasias, terrores e ilusões fascinantes que trazem chaves para o domínio da aventura da descoberta do eu, ao mesmo tempo desejada e temida. A destruição do mundo e a nossa própria destruição, seguida da "maravilhosa reconstrução de uma vida mais segura, ampla e completamente humana" (Campbel, 1997, p. 19). A função primária dos mitos e fábulas é fornecer os símbolos que levam o espírito humano a avançar nessa aventura através de processos catárticos.

O ciclo do herói se manifesta e realiza em milhares de histórias contadas e recontadas, com pequenas variações. O primeiro estágio é a partida ou afastamento do herói atendendo ao "chamado da aventura", seguida pela passagem dos "limiares" com auxílio de outras forças, o "ventre da baleia" ou mergulho no desconhecido, o estágio das provas e vitórias de iniciação e o difícil retorno ou reintegração com a sociedade, que pode ocorrer de forma destrutiva caso o herói tenha alcançado seus desejos através da violência. Será que este ciclo universal segue regendo as nar-

\footnotetext{
* Luiz Gonzaga Motta é Professor Titular da Universidade de Brasília (UnB). É Doutor pela University of Wisconsin com estágio de Pós-Doutorado na Universidade Autônoma de Barcelona. E-mail: luizmottaunb@yahoo.com.br.
} 
rativas comerciais pós-modernas e proporcionando 'autênticas' experiências éticas e estéticas?

Este artigo relata um exercício de análise da narrativa da canção "Faroeste caboclo", de autoria do compositor Renato Russo, da banda de roque Legião Urbana ${ }^{1}$. A música narra em 178 versos a aventura de um herói contemporâneo (ver anexo). O exercício aplica os procedimentos propostos pelo narratólogo russo Vladimir Propp (que analisou contos populares europeus) em um produto da indústria cultural para compreender a narrativa de um herói brasileiro moderno. A proposta de Propp (1984), embora ingênua em certos aspectos, e contestada por tantos autores, foi o marco inicial de uma metodologia interpretativa hoje conhecida como narratologia. As ideias originais de Propp foram bastante modificadas e sofisticadas posteriormente por inúmeros autores, especialmente os estruturalistas. Mas o trabalho pioneiro de Propp continua sendo um ponto de referência obrigatório para a narratologia contemporânea. Não há narratologia que não passe por Propp. Suas formulações originais continuam sendo um instrumento interessante de iniciação à narratologia e interpretação de histórias contemporâneas.

Haroldo de Campos (1973) procedeu a uma análise semelhante à que desenvolvo aqui do conto Macunaíma. Segundo ele, Mário de Andrade organiza sagazmente uma estrutura morfológica singular e unitária (um conto-mosaico) a partir de diversas fábulas brasileiras. Campos traça um paralelismo entre o trabalho pioneiro de Propp, que revela a estrutura monotípica das fábulas russas (suas funções invariantes), e o escritor brasileiro, que compõe uma rapsódia nacional recorrendo a inúmeras lendas autóctones. Coincidentemente, ambas as obras foram escritas em 1928, embora uma seja de natureza científica e outra artística² ${ }^{2}$.

Campos justifica a aplicação do método de Propp por outras razões,

\footnotetext{
${ }^{1}$ Conta-se que no dia em que Renato Russo morreu (11/10/1996) houve uma discussão na redação do Jornal Nacional, da TV Globo. A apresentadora Lílian Witte Fibe opunha-se a dedicar meio telejornal ao compositor. Willian Bonner, o outro apresentador, ameaçou recitar todos os versos de "Faroeste Caboclo" ali mesmo para convencer a colega da importância do compositor para sua geração. Convenceu e o telejornal dedicou metade de sua duração ao compositor. Essa e outras histórias da Banda Legião Urbana estão contadas no livro de Dapieve (2000).

${ }^{2}$ Em Macunaíma, diz H. de Campos, Mário de Andrade aboliu a diferença entre a criatividade de um contador tradicional e a realização individual do autor literário. Essa diferença estrutural fundamental é incorporada como regra do jogo literário: "Subsumindo-se na criatividade coletiva, apropriou-se do seu código de virtualidade e da sua tipologia para, através deles, exercer, como intérprete/co-produtor diante de uma partitura probabilística da música contemporânea, o virtuosismo de sua inventiva personalíssima. Daí a ambiguidade fascinante do seu livro.” (Campos, 1973, p. 72)
} 
entretanto. Segundo ele, a tabulação proppiana é um valioso instrumento para o estudo dos contos porque fornece uma ordenação pré-constituída dos elementos básicos da composição. No entanto, diz ele, a pertinência do método se impõe apenas como "hipótese de trabalho". Com isso ele se resguarda do "fascínio do método" (miragem ascética de alguns estruturalistas) e preserva uma correlação dialética entre método e obra: "a obra propõe o método de sua abordagem" assim como a metodologia "pode acabar sugerindo a obra que se lhe adeque" (Campos, 1973, p. 64).

Pretendo realizar aqui um estudo muito mais modesto. Trata-se de um exercício exploratório mais que uma aplicação sistemática das categorias de Propp. Nossos objetivos são mais simples: utilizaremos livremente os procedimentos de Propp tomados como "hipótese de trabalho". Não reivindicamos nenhuma fidelidade, até porque se trata de um exercício de um único produto da indústria cultural. O estudo pretende: 1) observar se a proposta de Propp é válida ainda como processo de interpretação semântica de uma narrativa produzida pela indústria cultural (produto de natureza comercial e fugaz, bastante diferente dos contos maravilhosos infantis, nos quais o autor russo se baseou); 2) observar se essa narrativa da indústria cultural repete o ciclo universal do herói guardando identidades com a natureza simbólica e psicanalítica das narrativas da tradição. Subjacente a estes dois objetivos, pretendo observar até onde uma narrativa comercial "empresta autenticidade" ao relato e segue expressando uma 'sabedoria', como a narrativa da tradição.

Com o ceticismo característico dos frankfurtianos, W. Benjamin (2001) em seu clássico ensaio "O narrador" advoga a tese do fim do narrador e da arte de narrar diante da avalanche de informações provenientes das notícias verossímeis da pós-modernidade. De fato, na sociedade de consumo, o que parece ter-se extinguido é o narrador artesanal da tradição, que S. Santiago (1989) chamou de 'narrador clássico': contador de estórias orais que relata seus testemunhos e experiências pessoais e aporta conselhos práticos, como observa Benjamin. Mas o narrador popular, ainda que utilizando novos suportes tecnológicos, não perdeu sua força simbólica na sociedade moderna. Ainda que tantas vezes efêmera e superficial, a arte de narrar persiste proporcionando experiências cognitivas, éticas e estéticas. Aí estão as canções populares, as telenovelas, filmes, raps, blogs, orkuts, twiters e outras formas pós-modernas de narrar que mantêm viva a narrativa e geram experiências densas tanto quanto a narração da tradição. Sherazade segue entre nós. A questão, como observa Santiago, é tentar compreender "o que é problemático na atualidade" (Santiago, 1989, p. 41). 
Minha hipótese coincide com a de J. B. Thompson (1998): quando mediadas pela indústria cultural as narrativas tradicionais são desenraizadas, se desritualizam, perdem a ancoragem tradicional (locais compartidos legitimadores da tradição). Mas não perdem a sua força simbólica de dar sentido ao mundo, retêm muitos conteúdos culturais tradicionais e realizam experiências e catarses iniciáticas que fornecem às pessoas os conteúdos semânticos necessários para compor suas identidades como seres no mundo. As narrativas tradicionais se modificam, se adaptam, são reimplantadas em novos contextos cotidianos e reancoradas em unidades territoriais mais amplas, mais abertas, mais fluídas e paradoxais. Mas realizam experiências simbólicas de igual intensidade.

\section{Questões metodológicas}

O trabalho pioneiro de V. Propp estava em busca de constantes comuns nas estruturas dos contos ${ }^{3}$. Para compreender essa estrutura o autor utilizou como ponto de partida os motivos parciais da história (partes constituintes) que se combinam para estruturar o enredo. O motivo seria primário, o enredo, secundário. $\mathrm{O}$ motivo pode relacionar-se em enredos diferentes, ampliando-se criativamente até produzir o conjunto. Mas o que Propp buscava não era apenas uma decomposição ou um catálogo de motivos unitários. Ele demonstra que os motivos exercem funções orgânicas em relação ao conjunto do enredo: "Por função, compreendese o procedimento de um personagem, definido do ponto de vista de sua importância para o desenrolar da ação" (Propp, 1984, p. 26). Função é, assim, o significado que a ação tem para o conjunto semântico do relato.

Partindo de Propp e outros formalistas russos, R. Barthes (1971) também reivindica que é preciso primeiro dividir o enredo em unidades narrativas mínimas, segmentos da história que se apresentam como termos de uma correlação. Ele observa que o critério de divisão é a significação dessas unidades para a o conjunto da história e que tudo na narrativa tem uma significação funcional (fortes correlações) para a história. Por isso, a

\footnotetext{
${ }^{3} \mathrm{O}$ termo estrutura não foi utilizado no trabalho original de V. Propp, membro da escola analítica conhecida como "formalismo russo". Ele utilizou o termo "morfologia" para descrever a forma constante das fábulas, especialmente as funções orgânicas dos "motivos" parciais das histórias. O antropólogo Levy Strauss apropriou-se trinta anos mais tarde desse procedimento, provocando um polêmico debate entre ambos sobre os conceitos de forma e estrutura e de forma e conteúdo. A partir de L. Strauss, os semiólogos franceses desenvolveram nas décadas de 1960 e 1970 uma narratologia estruturalista, fortalecendo o uso do termo "estrutura". Sobre isso, ver os anexos da versão brasileira do livro de Propp (1984).
} 
função é uma unidade de conteúdo: "é o que (um enunciado) quer dizer que o constitui em unidade funcional" (Barthes, 1971, p. 27). As funções são unidades semânticas básicas do ato narrativo, diz C. Bremond (1971).

Para exercitar a metodologia, diferentemente desses autores, identifico como funções em minha análise tanto as unidades significativas que expandem a história cronologicamente (as ações das personagens e as transformações sintagmáticas que expandem a história horizontalmente) como as unidades que caracterizam e identificam as personagens (estados ou "atmosferas" que expandem a história horizontalmente e que não seriam rigorosamente funções de acordo com a proposta original de Propp e da semiologia estrutural). Barthes chamou essas expansões verticais de índices. Em nosso exercício, as transformações temporais e causais conformam funções tanto quanto as expansões verticais (que R. Barthes considera como unidades verdadeiramente semânticas, mas não funções). $O$ exercício pretende buscar a integração da composição semântica em todas as suas expansões.

Justifico essa opção porque ambos os tipos de unidades desempenham funções integrativas no enredo e são definitivamente fundamentais para o sentido integral da história, embora concordemos com Barthes (1971, p. 30) que uma se relaciona mais com a funcionalidade do fazer e outra com a funcionalidade do ser; e que cada uma delas possa ser mais ou menos importante em diferentes tipos ou segmentos das narrativas ${ }^{4}$. Essa opção justifica-se também pelo tipo de narrativa a ser analisada, fortemente centrada no protagonista principal, em que os estados psicológicos da personagem cumprem a função de complementar e expandir suas ações. $\mathrm{Na}$ análise, procuro distinguir os momentos de expansão horizontal (temporal), ou do fazer, e momentos de expansão vertical, ou do ser (estados, atmosfera). Meu objetivo é observar como eles interagem e se complementam organicamente na sucessão temporal da história, sendo difícil isolar funções do fazer daquelas exclusivamente do ser.

Com o objetivo de melhor compreender a composição semântica integral, após realizar a operação nominativa, de identificar as unidades e suas funcionalidades, procuro agrupá-las em uma sequência quinária para ampliar o processo interpretativo, utilizando a divisão proposta por T. Todorov (1970). Uma sequência, segundo Barthes, é uma série lógica de núcleos unidos entre si por uma relação de solidariedade. Para essa

\footnotetext{
${ }^{4}$ Nas narrativas de ação (sagas, epopeias, romances, filmes de ação, etc.) as funções de transformação e desenvolvimento cronológico da história são muito mais frequentes e naturais. Nas narrativas psicológicas as funções de "atmosfera” estão mais presentes. A maioria das narrativas e dos gêneros literários, entretanto, constitui-se de uma mescla indeterminada dos dois tipos de função.
} 
etapa da análise serão consideradas como sequências o agrupamento de funções menores que venha a constituir uma unidade de significação mais ampla. Em resumo, trabalharemos com unidades semânticas inferiores (ações + "atmosferas") que conformam sequências (conjuntos semânticos intermediários) que estruturam um enredo. O enredo, por sua vez, projeta uma história e, em última instância, a fábula (o mythos da história). Nosso percurso parte de unidades semânticas inferiores para as superiores com o objetivo de compreender as partes e interpretar o todo orgânico.

Como diz C. Bremond (1971), toda narrativa consiste em um discurso integrando uma sucessão de acontecimentos de interesse humano na unidade de uma mesma ação. Essa integração não é só cronológica, a integração conforma a unidade narrativa maior que distingue a narração de uma simples cronologia (enunciação de fatos não coordenados). As condutas humanas oferecem os modelos e o narrador encadeia hierarquicamente as ações, explora na imaginação os desenvolvimentos possíveis, sempre orientados para um fim. Aos tipos narrativos elementares correspondem, portanto, as formas mais gerais do comportamento humano.

Esses procedimentos se justificam pelo esforço de compreender a lógica organizativa do conjunto narrativo. Como diz Barthes (1971, p. 38), ler é nomear, escutar é construir a significação de uma história: "a língua narrativa, que está em nós, comporta essas rubricas essenciais". E conclui com propriedade: "a lógica fechada que estrutura uma sequência está indissoluvelmente ligada a seu nome: toda função que inaugura uma sedução impõe desde sua aparição, ao nome que ela faz surgir, o processo inteiro da sedução, tal qual aprendemos em todas as narrativas que formam em nós a língua da narrativa". Os nomes e designações são, porém, arbitrários.

A compreensão das articulações internas precisa também observar as relações desses blocos semânticos, os "saltos para trás e para diante", os elementos contínuos e descontínuos e entender as rupturas (brandas e radicais) que se realizam nos níveis inferiores e superiores do transcorrer do enredo. A narrativa é uma linguagem sintética fundada sobre o encadeamento, desenvolvimento e síntese, o que é separado reúne-se novamente no superior. É assim que a narrativa anda. (Barthes, 1971, p. 52-6).

Diferentemente dos estruturalistas, porém, considero que o desenvolvimento cronológico (temporal) é a essência que encadeia os acontecimentos e as "atmosferas" (estados) narrativas. Para mim a sintaxe funcional se estabelece desde uma lógica de sucessão cronológica (mesmo nas "atmosferas" ou "índices") e essa lógica é a lógica humana (Motta, 2005). Sigo aqui a Ricoeur (1994, p. 85), que afirma existir uma correlação cul- 
tural entre a atividade de narrar uma história e o caráter temporal da experiência humana. $\mathrm{O}$ enredo, diz ele, tece e configura a nossa experiência temporal de mundo, medeia e integra acontecimentos individuais em uma história, um ato configurante que sintetiza o heterogêneo: "compreender uma história é compreender como e por que os episódios sucessivos conduziram a uma conclusão" (Ricoeur, 1994, p. 105). Um tempo que escoa do passado em direção ao futuro ${ }^{5}$.

\section{Breve análise das funções orgânicas do enredo de uma história}

A versão da música "Faroeste Caboclo" utilizada nesta análise tem 178 versos que estruturam o enredo de um conto centrado na trajetória de João de Santo Cristo, protagonista principal (ver anexo). Através de procedimentos analíticos, o enredo pode ser dividido em conjuntos unitários mais ou menos coesos de significação. Essa divisão, entretanto, é arbitrária e não guarda absoluta coerência. Ela depende do olhar analítico. Alguns versos atribuídos a um determinado episódio poderiam estar igualmente em outros; versos do mesmo conjunto não se seguem linearmente e precisam ser buscados adiante, pois o autor compõe com a liberdade de artista e a composição é o resultado da espontaneidade da criação. O agrupamento analítico não é absoluto nem integralmente coerente, portanto.

Minha divisão da letra da música identifica 30 motivos (28 funções mais a situação inicial e o epílogo), que constroem organicamente o conjunto significativo do enredo, conforme apresentamos em seguida. A divisão da narrativa em partes justifica-se por ser uma decomposição analítica do todo, supondo que cada episódio unitário exerce uma função orgânica em relação ao conjunto da narrativa e a compõe como uma síntese, conforme argumentamos acima. Passo às operações nominativas e identificação das 30 funções (Fs) da letra da música "Faroeste Caboclo". Ao final, farei breves referências aos significados narrativos da melodia.

Situação inicial: o herói buscador - Essa função corresponde à "situação inicial", terminologia utilizada pela maioria dos analistas. Em Propp, essa função não tem número, corresponde ao zero. No enredo em análise, a primeira função está circunscrita aos quatro primeiros versos, em que

\footnotetext{
${ }^{5}$ Ricoeur (1994, p. 214-6) diz que seguir uma história é compreender as ações, os pensamentos e os sentimentos sucessivos enquanto apresentam uma sucessão particular. Somos impulsionados para frente pela expectativa em relação ao desenlace do processo. O autor argumenta contra a semiologia estruturalista que considera apenas as leis internas da obra literária. Em contrapartida, uma hermenêutica deve preocupar-se em reconstruir o arco inteiro da experiência narrativa, desde a cultura (préconfigurante) até a recepção (reconfigurante), mediada pela obra (configurante). Minha proposta de análise pragmática da narrativa está apresentada em Motta (2005).
} 
o protagonista é apresentado como alguém destemido que quer lançar-se na aventura da vida. Sua saída deve-se ao fato de "sentir no seu sangue o ódio". Insinua-se que sua frustração com a vida é resultado da descrença na moralidade humana, nos ensinamentos da moral cristã subentendida pela menção a Jesus.

Sabemos, por versos subsequentes, que o herói mora no interior do estado da Bahia, e deixam pressuposto que a virtude da bondade está na fazenda, na vida do campo, espaço/moral ingênuos deixados para trás. Mas falta aí alguma coisa que o herói quer buscar. J. Campbell (1997, p. 66) chama esse estágio da jornada do herói de "o chamado da aventura" significando que o destino o convocou para algo ou para uma região desconhecida. A aventura pode começar com um mero erro, o herói pode mover-se a esmo e algo o atrair, pode mover-se por vontade própria, pode ser levado para longe por um agente benigno ou maligno. Nossa narrativa começa assemelhada à tradição, portanto.

F1: A identidade e a diferença: perversidade - A função número um corresponde aos versos 5 e 6, complementados pelos versos 13 e 15. Esses versos funcionam como uma analepse (flashback) que recapitula para o ouvinte a origem da revolta interior do herói: o assassinato do seu pai por um soldado (o sistema). Nesses e outros versos, o "sistema" funciona vagamente como um antagonista difuso que inflige danos morais ao protagonista. No transcorrer do enredo o sistema aparece como uma classe social alta, antagônica à classe marginal do herói. Os primeiros versos deixam claro um rancor nato no herói, um estigma de perversidade e diferença, trazem implícita uma inquietação interior do herói e seu desejo de deixar o lugar. Carimbam o herói com o estigma do mal. Ele quer libertarse, lançar-se na vida. Sua janela para o mundo exterior ao provincianismo local é a televisão e o seu horizonte é o mar, a imensidão do mar, símbolo de amplitude e de liberdade. Essa função carimba o herói com qualidades negativas e recapitula fatos anteriores fundamentais para a saga que se vai narrar.

F2: Rebeldia/Transgressão - A função dois está compreendida nos versos 7 a 10 e 17-18. Essas estrofes descrevem as ações rebeldes e malignas do herói. Complementam a função anterior e a desenvolvem. $\mathrm{O}$ herói-criança é a imagem da maldade, infernizava a vida das meninas, do professor e das velhinhas católicas, ou seja, do establishement. A inquietação e a rebeldia do herói manifestam-se nas suas ações malignas e cruéis. O herói trafega na transgressão, é mau, perverso. A narrativa está aqui em franca decadência (no sentido moral da palavra), que C. Bremond (1971) chama de degradação. 
F3: Primeira Queda - A degradação chega ao fundo do poço nos versos 19 e 20 (função três). O herói é enviado à prisão (um reformatório) pela primeira vez, resultado de sua crueldade. Manifesta-se aqui de forma mais explícita a luta do herói contra o establishment. Prisões e reformatórios são os órgãos da coerção punitiva para os "marginais" em relação aos comportamentos sociais consensuados. Aqui há uma evolução cronológica da história, mas também uma função psicológica: aumenta o ódio interior do herói rebelde contra o sistema.

F4: Inquietação - A função quatro está contida nos versos 11-12 e 21 a 22. Essa função não se compõe de ações, não indica evolução cronológica da história, como as anteriores. Tem um caráter psicológico, volta-se para o interior da personagem. Ela cumpre a função de revelar o interior da personagem, sua indignação contra o sistema, sua revolta interior. O herói "sentia-se" diferente, discriminado e frustra-se. As qualidades morais degradantes são decorrentes das frustrações psicológicas. Os verbos utilizados nestes versos são verbos de sentimento (sentir, entender). R. Barthes (1975) chama essas funções que não fazem a história progredir de catálise. Diversas descrições podem acrescentar qualidade ao relato (ao cenário, às personagens etc.), mas sem indicar avanço cronológico.

F5: Saída - Os versos 15 e 24 descrevem a decisão do herói de sair (função cinco). O herói deixa finalmente o seu local de origem em busca de novos horizontes. Todo conto, segundo Propp, começa com a saída de um herói que se ausenta. Confirma-se também aqui uma semelhança entre a narrativa da indústria cultural e aquelas da tradição. No enredo em análise, é a revolta interior e o mau ajustamento ao ambiente que provocam um desejo de saída, de busca. Por isso, o herói junta dinheiro para deixar o lugar de origem, para libertar-se para o mundo. Ficamos sabendo aqui que o herói é baiano do interior, um nordestino retirante.

F6: O rumo - Os versos 25 a 33 poderiam ser desmembrados em mais de uma função porque relatam inúmeras ações e transformações parciais em um ritmo intenso para a evolução cronológica da história. Preferimos, entretanto, agrupá-los para efeito de economia da análise. Eles contêm inúmeros detalhes, mas a sua significação orgânica para a história é a ocasional ida do herói para Brasília. É isso que torna esses versos uma unidade significativa (função seis) orgânica para o conjunto da história. Eles relatam o encontro ocasional do herói com um boiadeiro que muda o rumo de sua busca. O herói é levado para longe. $\mathrm{O}$ autor parece querer explicar porque o herói chega à Brasília e atribui isso ao acaso, a uma intervenção espontânea do destino. O herói aceita a oferta de um desconhecido e toma um rumo ocasional, Brasília, a capital do país, cidade símbolo do sonho dos nordestinos. 
F7: Deslumbramento - Os versos 34 a 38 revelam o deslumbramento que se apossa do herói em sua entrada em Brasília na época do Natal, quando a cidade fica toda iluminada com lâmpadas decorativas (função sete). O deslumbramento não é um episódio gratuito, entretanto. Ele significa uma ascensão moral da narrativa, que $\mathrm{C}$. Bremond chama de "melhoramento", e prepara o leitor para as ações que serão descritas na sequência. Nestes versos a história cresce moralmente, o herói se ilumina interiormente, efeito de encontrar um mundo diferente do seu inexpressivo e opressor local de origem. E toma a decisão de seguir o "mundo do bem", de começar a trabalhar imediatamente (no ano-novo que se aproxima). Embora aqui haja evolução temporal, o episódio tem uma relação orgânica mais psicológica que cronológica no desdobramento da narrativa. Há uma transformação interior do herói.

F8: Reconciliação (com o bem) - Os versos 39 a 43 organizam outra função. Nesses versos o herói busca se reconciliar com o bem, tenta crescer na vida dentro do sistema. Começa a trabalhar como aprendiz de carpinteiro, ganha dinheiro e conhece gente interessante. A expressão "rapaz trabalhador" qualifica o herói com uma qualidade diferente das qualidades perversas anteriores, indica uma mudança de estado do protagonista. Uma transformação importante no percurso do herói. Ele agora está trilhando o rumo do bem, reconciliando-se com o status quo. Há uma significação positiva, um melhoramento explícito.

F9: Primeira doação (doador) - Os versos 44 a 45 introduzem uma personagem nova no enredo, um parente distante que realizava comércio e ia abrir um novo negócio. Essa personagem não tem intervenções fortes no decorrer da narrativa, mas realiza a tarefa de induzir o herói a novas ações. Ela não é exatamente uma doadora como em contos clássicos em que uma personagem intervém decisivamente para alterar o percurso do herói. Essa personagem (o boliviano Pablo) é neste enredo relativamente discreta, mas realiza coisas importantes para o herói.

F10: Segunda Degradação - Os versos 49 a 54 revelam nova "queda" de moral do herói. Ele estava fazendo um esforço e "até a morte trabalhar", levar uma vida de bem. Mas o dinheiro não dá, mesmo com o sistema (o ministro) repetindo que ia ajudar. Desiludido, o herói toma a decisão de "se virar", de agir por si próprio. A decisão prepara o leitor para compreender as ações que serão descritas pelos versos seguintes.

F11: Nova Transgressão - Os versos 55 e 56 revelam novas ações e uma mudança de rumo no enredo (ponto de virada). Frustrado, o herói reage, deixa o trabalho no "sistema" e volta para o mundo da transgressão. Ele começa uma plantação de maconha (a palavra não aparece, talvez para 
evitar problemas com a polícia à época) e transforma-se em traficante bem sucedido (sem ser "crucificado"). A narrativa está novamente rumo à degradação moral da personagem principal, apesar do sucesso comercial. Depois da tentativa de transformar-se em um cidadão do bem, o herói cai na tentação e faz nova opção pela transgressão.

F12: Mergulho na marginalidade - Os versos 57 a 63 formam um conjunto unitário que revela o sucesso do herói no mundo da transgressão. Ele triunfa no mundo marginal, é bem sucedido como traficante, vende "bagulho", delimita o seu território (imagem comum do bandido bem sucedido no mundo do tráfico de drogas), faz amigos e passa a frequentar ambientes nobres (festas na Asa Norte, bairro classe média-alta de Brasília) distantes do seu status marginal anterior.

F13: Segunda Queda - Os versos 65 a 70 relatam nova degradação e queda do herói. Ele assume completamente a marginalidade, começa a roubar. Porém, é apanhado e levado à prisão pela segunda vez na história. Amarga então o mundo cruel das prisões, é torturado e estuprado, sofre o inferno (voltaremos adiante ao significado religioso desta palavra na narrativa). Manifestando sua revolta, que retorna intensamente, jura vingança. A formação psicológica do herói vai ganhando densidade. Observe-se que Renato Russo isenta o herói de culpa. A opção do herói pelo mundo do mal é justificada pelo autor: ele começa a roubar "sob má influência dos boyzinhos da cidade". O mal não está no herói, mas na classe social antagônica que o corrompe.

F14: Identidade e diferença: estigma - A função seguinte corresponde aos versos 71 a 74, quando o herói ganha o estigma de bandido temido, sem medo. As opções do herói se reduzem, ele já não pode fugir da mácula que o identifica, está de uma vez carimbado como marginal. Consolidase nesta função a formação psicológica do herói. Suas opções se restringem, ele carrega a marca da transgressão. A história está novamente em um momento de franca degradação moral. Essa função também não faz a história avançar cronologicamente, mas não deixa de ser uma consequência causal da função anterior. A partir do primeiro verso desta função o ritmo da melodia se acelera, transforma-se em um roque mais pesado dando suporte ao quase-clímax que a narrativa atinge.

F15: Paixão e deslumbre - Os versos 75 a 83 vão marcar uma nova mudança radical na história. O herói conhece uma menina e se apaixona. $\mathrm{O}$ amor provoca novamente na história um momento de ascensão moral e melhoramento. Ele se deslumbra e se reconcilia novamente com o bem. $\mathrm{O}$ herói se arrepende dos pecados, volta a trabalhar como carpinteiro, quer se casar, todos indicadores positivos de ascensão moral. O herói sonha em 
formar família, ter filho, tenta erguer-se moralmente. Essa função é um exemplo interessante de evolução do enredo, um ponto de virada que na verdade revela uma forte mudança psicológica interior da personagem. Nesses versos o ritmo se ralenta novamente.

F16: Sedução do mal - A função seguinte é composta pelos versos 84 a 86. Há uma tentativa de suborno por parte de um antagonista. Neste segmento, em sua jornada, o herói é posto à prova. Todo herói precisa ser posto a provas. Um agente do mal tenta seduzi-lo, faz-lhe uma proposta indecorosa e oferece dinheiro. Na maioria dos contos analisados por Propp, o herói é posto à prova, que o prepara para receber uma ajuda. Num dos tipos de prova identificados por ele, alguém oferece ao herói um objeto mágico (o dinheiro) e propõe-lhe uma troca. No ciclo do herói de J. Campbell (1997) as provas são parte dos rituais de iniciação. O ritmo da canção em análise, que se havia ralentado, volta a se acelerar e transforma-se novamente num roque.

F17: Recusa - A próxima função revela a reação do herói frente à tentação. Os versos 87 a 93 mostram a recusa do herói frente à oferta indecorosa. A narrativa ganha um ritmo intenso. A ascensão moral está aqui no seu ápice. A referência a crianças denota a dignidade do herói. $\mathrm{O}$ agente do mal aparece claramente aqui como algo exterior ao herói, alguém que vem de fora corrompê-lo. As referências a "senhor de alta classe" e "general de cinco estrelas" revelam que o mal está em outra classe social diferente daquela do herói.

F18: Ameaça - Os versos 94 a 100 reforçam a sedução do mal, a radical perversidade do agente externo frente à recusa do herói em aceitar a tentação. O herói é ameaçado e a ameaça surte efeito. O herói parece não ter superado inteiramente a tentação, sabe que vai sofrer as consequências da recusa. A inquietação que toma conta de novo o herói, que estava estabilizado. O herói está transtornado, se debate internamente entre o bem e o mal, as ameaças penetram seu coração. O papel dos antagonistas, segundo Propp, é destruir a paz, provocar danos e prejuízos e aparece sempre furtiva e aleatoriamente. Na primeira vez em que o antagonista repete sua ameaça, o ritmo se ralenta novamente, ecoando a ameaça.

F19: Terceira degradação - O regresso ao mundo marginal é a síntese dos versos 101 a 105. O autor intervém para fazer um comentário pessoal sobre a história que está sendo narrada nos versos 101 e 102, preparando o leitor para os acontecimentos que vão ser confirmados nos versos seguintes. O herói se embebeda, falta ao trabalho e perde o emprego. A narrativa começa a revelar uma nova queda moral. O herói não resiste à tentação, sucumbe novamente. Essa é a função desses versos. 
F20: Novamente a transgressão - O herói volta-se mais uma vez para o mundo marginal e mergulha na transgressão como parceiro de seu primo Pablo. Torna-se mais uma vez um bandido traficante. Não resiste à prova, experimenta nova queda. Essa é a função dos versos 106 a 109. O enredo revela origens geográficas do contrabando (Bolívia, fonte de contrabando para o Brasil segundo notícias de jornal) e a região de atuação do herói (Planaltina, cidade satélite do Distrito Federal) para conferir maior verossimilhança à narrativa. É clara aqui a influência do noticiário na construção da narrativa musical.

F21: Desafio ao herói - Essa função correspondente aos versos 110 a 113 , em que um novo antagonista (Jeremias), também do mundo da marginalidade, traz um novo desafio para o herói, a disputa de território. Observe-se que o autor está sempre introduzindo antagonistas. Na análise de Propp, esse ato corresponderia a uma declaração de guerra. Mais uma prova para o herói: sua possível aniquilação pelo rival. Observe-se que o antagonista é apresentado como sem-vergonha, mentiroso que fazia mal às mocinhas inocentes, várias qualidades negativas. Propp afirma que os variados danos que os antagonistas provocam no herói são uma das funções mais importantes porque dão movimento ao conto e algumas funções anteriores são apenas preparação para esses desafios.

F22: Doação - O doador (ou provedor) é, para V. Propp, um agente que transmite ao herói um objeto mágico. A personagem Pablo, parente do herói, não é exatamente um doador, pois não oferece ao protagonista nenhum objeto mágico. Ele aparece discretamente como contrabandista, alguém que ganha dinheiro fácil com a marginalidade, no início da história e provê o herói com possibilidades de arranjar a vida em momentos de incerteza. É alguém que está sempre por perto, disponível quando necessário. Nos versos 114 a117 provê o herói com uma arma, objeto que realiza coisas fundamentais no mundo da marginalidade. Observe-se que estes versos dizem que, apesar de saber atirar, o herói só vai fazê-lo em legítima defesa (depois que Jeremias começar a brigar).

F23: Queda moral - Os versos 122 a 130 marcam uma nova queda moral do herói. Dessa vez não é a prisão, mas ele desce novamente ao "inferno" quando regressa a casa disposto a se casar e descobre que a amada, de quem sentia saudades, é amante do seu rival, de quem vai ter um filho. O antagonista rapta a amada do herói, que é "só ódio por dentro". No transcorrer do enredo, o herói está enfrentando diversas adversidades e provas. Essa função é mais uma delas. A narrativa está novamente no fundo da degradação moral.

F24: Vida ou morte - O herói reage ao rapto da amada e desafia o 
antagonista para um duelo de vida ou morte. Esse desafio é a função dos versos 131 a 137. Grosso modo, poderia dizer-se que o herói está quebrando um interdito. Ele deveria seguir o caminho do bem, ser magnânimo, perdoar a amada e o adversário. Mas, ao contrário, reage e promete matar o adversário e a ex-amada, agora menina falsa. Segundo Propp, esse momento é característico dos contos do herói-buscador. A partir do verso 129 dessa função (anuncia que o antagonista fez um filho na amada), o ritmo se aquece novamente, permanecendo acelerado até o final da música.

F25: O espetáculo - Os versos 138 a 144 marcam certo atordoamento do herói frente à publicização do duelo com o seu oponente. Sem saber o que fazer, talvez quisesse recuar. Mas a entrada da TV torna o desafio um espetáculo para o público, com local e hora marcada. Não há retorno. Aqui, o autor introduz na sua narrativa uma crítica à sociedade-espetáculo, onde tudo se transforma em show. A canção-narrativa, como não poderia deixar de ser, revela-se inserida no contexto da sociedade midiática.

F26: Morte covarde - O antagonista fere de morte o herói, porém os versos 145-147 se referem menos ao ato em si e muito mais ao oponente, descrevendo-o como um homem covarde e frio, que atira pelas costas e sorri. Desqualificar o antagonista reforça a qualificação do herói. O herói só vai morrer porque o antagonista atirou pelas costas. Mais uma vez, Renato Russo poupa seu protagonista.

F27: A última queda - Ferido de morte, o herói agoniza em um delirium-tremens. Sangue na garganta, sol nos olhos, relembra sua vida inteira. Essa penúltima função da história é descrita nos versos 147 a 153. Ainda agonizando, o herói revolta-se com o espetáculo de sua morte, e parece procurar uma saída: "se a via-crúcis virou circo, estou aqui", diz a frase do verso 156.

F28: Desenlace: a vingança final - A última função do enredo propriamente está contida nos versos 157 a 169. O herói ainda tem forças para reagir pela última vez ao reconhecer a amada que lhe traz a arma doada antes pelo primo provedor. Revelando suas qualidades e distinguindo-se do antagonista pela honradez, chama o oponente para que ele se vire de frente, e o mata com cinco tiros, antes de também morrer. Faz-se justiça, o inimigo é castigado e a amada se redime no momento final. Ela se arrepende e morre junto (morte não explicada na canção). A significação do desenlace é atribuir um fecho ao enredo, outorgar-lhe uma dimensão unitária integral. Reis e Lopes (1988) definem o desenlace como um conjunto concentrado de eventos que resolve tensões acumuladas e institui uma situação de relativa estabilidade irreversível (uma morte, um casamento, uma conquista). O último ato da biografia do herói, diz J. Campbell (1997, 
p. 342), é a sua morte ou partida, que resume todo o sentido de sua vida. $O$ herói, que em vida representa uma perspectiva dual (a bondade e a maldade), ainda é, depois da morte, uma imagem síntese: "ele apenas dorme e se levantará na hora que o destino o determinar, ou estará entre nós sob outra forma." A história poderia concluir-se com estes versos. Está contada a história e concluída a narrativa em sua coerência integral.

Epílogo: o herói-santo - Mas o autor introduz ao final um epílogo (versos 170 a 178), um comentário próprio a respeito da personagem principal deixando pistas de como ele quer que o conjunto dos múltiplos episódios da história narrada seja interpretado. Esses versos referem-se a um tempo posterior ao tempo da história no enredo. A morte do herói o transforma num santo, alguém que continua entre nós sob nova forma, com qualidades além do humano, embora o autor diga explicitamente nos últimos versos que o herói não conseguiu realizar o que pretendia: ajudar o povo brasileiro. As inquietações e buscas do herói no início e desenrolar da história ganham com a intervenção do autor uma dimensão política que estava apenas sugerida no enredo. O epílogo revela, com maior clareza, o objetivo do autor ao formular a sua narrativa musical. O ritmo segue acelerado até o fim da música, acompanhando o final dramático da história.

A narrativa musical - Nosso objeto de análise recaiu sobre o discursivo. Mas não se pode ignorar a pontuação que a música introduz na narração. Os versos que compõem o enredo são sustentados pela melodia que funciona como uma moldura, de duração ligeiramente mais longa que o relato discursivo. Essa moldura delimita a duração da história, que começa e acaba dentro dos marcos da melodia. Ela condiciona a narrativa ao tempo da execução musical. Funciona como abertura e fechamento dramáticos. A música é longa para os padrões comerciais, dura cerca de nove minutos, revelando que o autor quis contar a sua história com relativa independência em relação às exigências comerciais. Sua recepção se realiza em ambientes segmentados (audiência pessoal) porque raramente essa música é executada nas emissoras comerciais devido a sua longa duração.

No caso de "Faroeste Caboclo", o ritmo musical funciona como suporte que cadencia todo o andamento narrativo. A melodia começa com a batida de um violão num ritmo lento de um reggae-canção que se acelera em algumas passagens e transforma-se em um rock mais pesado com acompanhamento de guitarra e bateria quando o autor imprime velocidade maior ao ritmo da narrativa para realçar aspectos dramáticos de certas passagens. Volta à balada-reggae do violão solo quando o autor quer amenizar os efeitos dramáticos. A linguagem musical sonora se so- 
brepõe e se sincroniza, portanto, com a verbal. As duas linguagens estão sintonizadas (isocronia) compondo o significado integral da obra. O recurso musical amplifica o processo de comunicação narrativa na medida em que projeta significações de uma linguagem complementar paralela à interpretação verbal do ouvinte. As oscilações musicais projetam-se, portanto, na cadeia temporal da narrativa sobrepondo e condicionando significações da composição integral.

Sequência quinária: Aplicamos o modelo de sequência quinária proposto por T. Todorov (1970, p. 138) para adicionar recursos de interpretação à nossa análise semântica e identificar a sequência maior 6 . Esta sequência se compõe de cinco estágios: situação estável inicial, ação de uma força perturbadora, desequilíbrio, força inversa, reequilíbrio. Na canção em análise, a situação estável (embora sem rigidez) vai dos versos 1 a 52, quando a personagem busca firmar-se na vida através de várias tentativas. A força perturbadora manifesta-se através das inúmeras seduções que atraem a personagem para o caminho do crime e marginalidade. Distribui-se do verso 52 até o início dos versos 100. O desequilíbrio revela-se na adoção pela personagem da transgressão, tornando-se malfeitor e traficante. $\mathrm{O}$ estigma de bandido o identifica. Distribui-se aleatoriamente entre os versos 50 e o 130. A força inversa é o amor e a bondade, manifestados no desejo da personagem de trabalhar, de praticar o bem, igualmente distribuída aleatoriamente nos versos centrais do enredo. Finalmente o equilibro é restabelecido com a morte da personagem, narrada do verso 145 em diante e completada no epílogo. Esse reequilíbrio é, obviamente, diferente do equilíbrio inicial, conforme argumenta T. Todorov.

\section{A saga do anti-herói}

A análise empreendida até aqui revela que o enredo da história relatada pela canção de Renato Russo está fortemente concentrado na figura de um único protagonista, João de Santo Cristo. Ele se lança na aventura do mundo, comete erros, cai, ergue-se novamente, busca incessantemente, aventura-se no bem e no mal. O enredo está todo centrado nas dramáticas

\footnotetext{
${ }^{6}$ Todorov (1970, p. 138 e ss.) sugere que o enredo mínimo completo consiste da passagem de um equilíbrio a outro. Uma narrativa "ideal” começaria com uma situação estável que uma força qualquer vem perturbar. Disso resulta um estado de desequilíbrio. A ação de outra força, dirigida em sentido inverso, pressiona para restabelecer o equilíbrio. Mas o novo equilíbrio não é igual ao primeiro, é diferente. A ação dessas forças estabelece uma sequência quinária, portanto. Uma sequência é, para ele, uma unidade sintática superior. A sequência provoca uma reação intuitiva do leitor, que reconhece a história completa.
} 
ações, transformações e estados psicológicos dessa personagem principal, que se sucedem e se sobrepõem em um ritmo intenso. As demais personagens têm papel secundário no enredo, ainda que, ao final, um antagonista assuma relevância maior no desfecho da história. Mas ele surge e age apenas com a função de proporcionar ao herói suas últimas façanhas.

"Faroeste Caboclo" não relata, evidentemente, o ciclo completo típico do herói (Campbell, 1997, p. 40 e ss.). João de Santo Cristo tem qualidades de um herói clássico: supera as limitações pessoais e locais, recebe os chamados da aventura e lança-se nela, passa por provações, desafios e provas na sua busca rebelde, enfrenta a tentação feminina, recebe ajuda de um provedor, passa pelos limiares e é beatificado ao final. Mas João de Santo Cristo encarna mais apropriadamente o anti-herói, figura frequente na literatura e cinema brasileiros contemporâneos.

Em um país marcado pela exclusão social, migração descontrolada, urbanização acelerada, pela marginalidade e a violência na periferia das grandes cidades, a arte brasileira contemporânea (romances, filmes, canções, videoclipes etc.) recupera com frequência a figura do anti-herói. João de Santo Cristo encara mais apropriadamente nossas contradições sociais e culturais: é um herói de caráter contraditório, bom e mau, perverso e protetor, vítima do sistema, rebelde e revolucionário, cínico e cruel, que se debate entre a comunhão e a oposição ao mundo.

A representação mais emblemática desse tipo de herói na arte brasileira é, evidentemente, Macunaíma, personagem de Mário de Andrade, que é simultaneamente herói e anti-herói, vilão e antivilão. Haroldo de Campos observa que as qualidades espirituais de Macunaíma são paradoxais: ele é preguiçoso para o trabalho, mas esperto diante do dinheiro e mulheres. Cospe na cara dos índios varões, mas respeita os velhos, é irreverente e moleque, mas inteligente e simpático: "seu caráter está justamente em não ter um caráter definido" (Campos, 1975, p. 110). Herói-síntese do bem e do mal, múltiplo e contraditório 7 . João de Santo Cristo, personagem de nossa análise, revela também essa contraditória personalidade: encara dualística e simultaneamente o bem e o mal.

Por sua complexidade, João de Santo Cristo pode ser considerado uma "personagem redonda" (densa) ${ }^{8}$. Apresenta qualidades e defeitos que

\footnotetext{
${ }^{7}$ Haroldo de Campos reproduz uma carta de Mário de Andrade a Tristão de Ataíde em que ele revela o fascínio do autor pela personagem: “percebi que Macunaíma era um herói sem nenhum caráter nem moral nem psicológico, achei isso enormemente comovente nem sei por que (...) rindo apenas das alusões à psicologia do brasileiro que botava nele (...) tanto simbolismo até, que nem sei parece uma sátira tremenda.” Mas corrige: “E não é não” (Campos, 1975, p. 111). Em várias passagens do seu livro, Haroldo de Campos revela a inquietação de Mário de Andrade com sua ambígua personagem.

${ }^{8} \mathrm{O}$ autor inclui inúmeras "instruções de leitura" para criar sua personagem principal. Utiliza-se de
} 
surpreendem o ouvinte, alternando valores do bem e do mal, sentimentos nobres (trabalhar, constituir família, ser justo) com sentimentos ignóbeis (ódio, rancor, crueldade). Desde o início da história ele se percebe diferente, excluído e marginal, o que o leva a inquietações interiores, carências e inconformismos, manifestados em ações perversas. O herói é um ser revoltado, rebelde, que opta pela vida de bandido e pela transgressão, mas não sem contradições. Em certa medida, assemelha-se ao Trickster, um herói moleque indiano estudado por C. Jung, personagem dominada pelos seus apetites (físicos e psicológicos) que tem como objetivo satisfazer as suas necessidades elementares. É cruel, cínico e insensível ${ }^{9}$.

Como muitos anti-heróis brasileiros, entretanto, ele é vítima do "sistema", de classes sociais diferentes da sua. No transcorrer da narrativa ele é vítima sucessivamente de soldado, de ministro, de boizinhos, de general, de burocratas, da polícia, da sociedade-espetáculo e, ao final, da "alta burguesia". Fica subentendido que hipócrita é a outra classe, uma antagonista "de fundo" que gera a exclusão e a discriminação. As marcas neste sentido são inúmeras no texto do enredo. É um soldado (força coercitiva do sistema) que o priva do pai (verso 6); ele trabalha duro, mas o dinheiro não dá (v. 50); ouvia o ministro anunciar ajuda, que nunca veio (v. 52); começa a roubar "por influência de boyzinhos" (v. 65); é um "senhor de alta classe" que lhe faz proposta indecorosa (v. 84).

O autor poupa sempre o herói e deixa, algumas vezes, escapar a sua simpatia por ele. O herói quer o bem, se arrepende dos erros, tem sentimentos nobres (não aceita a propina para realizar uma "ação suja", não atira pelas costas). Definitivamente, é vítima, por isso delinquente. $\mathrm{O}$ antagonista que o desafia entra na história para proporcionar contraste com herói, para revelar as suas boas qualidades e ações. A função do antagonista é fazer oposição e causar danos ao herói para salientar suas qualidades. Como sempre, o mal é necessário para revelar o bem. Embora tenha semelhanças pessoais com o herói, Jeremias, o antagonista, é mau caráter, "maconheiro sem vergonha", mentiroso, covarde (atira pelas costas), perverso (atira e sorri). Na história, os dois cometem as mesmas ações

vários artifícios de linguagem articulando o ser e o fazer em cadeias de correferência para dar a ela a consistência pretendida. Constrói a imagem do herói tanto pelas suas ações como por breves qualificações e algumas falas da própria personagem.

${ }^{9}$ Carl Jung se refere ao Trickster, um mito indiano, como uma figura de natureza dupla, mutante, em parte divertida, em parte maligna, mas próximo da figura de um salvador. É um ser originalmente cósmico, de natureza divino-animal, ao mesmo tempo superior ao homem na sua qualidade sobrehumana e inferior a ele na sua insensatez inconsciente. (Jung, 2000, p. 251-66) 
em relação ao sexo feminino, mas o tratamento é diferenciado. Enquanto o herói "comia" as menininhas, Jeremias "desvirginava mocinhas inocentes".

Essa estética da contradição social impregnou recentemente o cinema brasileiro e se tornou conhecida como "estética suja". Filmes importantes como Cidade de Deus, Carandiru, Amarelo manga e outros representam o movimento chamado "Retomada do cinema brasileiro". A temática realista, quase documental, é tomada emprestada da cobertura jornalística, e a linguagem importa recursos do videoclipe e da publicidade. O cenário comum é a periferia violenta dos grandes centros urbanos, onde a presença do Estado, da religião, da escola e da igreja é escassa e a consciência de cidadania é uma utopia remota (Lusvarghi, 2005). As personagens principais "são pessoas marginalizadas - presidiários, traficantes, travestis, desempregados, $\neg$ em conflito com a cidade global, a cidade do poder". A música "Faroeste Caboclo" (que está sendo transcrita para o cinema) é precursora dessa estética, ainda que contenha características distintas porque foi composta por Renato Russo em 1979, quando ainda estávamos sob a ditadura militar (a música só foi lançada no $\mathrm{CD}$ Que país é este?, em 1987).

\section{Significado profundo: o percurso da aventura do herói}

A análise permite observar também que "Faroeste Caboclo" tem o seu fundo mítico ou motivo ético e estético profundo. Na verdade, a história reconta parcialmente a saga de Jesus Cristo, adaptada a um cenário contemporâneo. Há inúmeras marcas no texto que remetem a essa interpretação. O nome da personagem principal não é aleatório, faz uma referência explícita a Cristo e a um santo. Os nomes das personagens são todos bíblicos: João, Pablo, Jeremias, Maria. Eles compõem a atmosfera mística à qual o autor quer remeter seus ouvintes. João de Santo Cristo percorre um percurso de sofrimento, privações e punições. Ao final, é punido com uma morte pública dolorosa e perdoa Maria.

Há muitas outras pistas para corroborar essa hipótese. Nos versos 55 e 56 o autor se refere a um "plano santo" da personagem, sem "ser crucificado", quando o herói está, neste momento da narrativa, em processo de degradação. Duas vezes, nos versos 68 e 127, a letra da música menciona que o herói desceu ao inferno e no verso 175 diz que ele foi "com o diabo ter". No verso 156 a menção é ainda mais explícita, o herói chama seu sofrimento de "via crucis", o caminho de sofrimento percorrido por Jesus Cristo. Finalmente, no desfecho do enredo, ao morrer digna e gloriosa- 
mente, João de Santo Cristo é declarado santo pelo povo. Nenhum herói morre, diz J. Campbell, ele renasce ou volta de outra forma, permanecendo entre nós. João de Santo Cristo é o herói-migrante brasileiro sofredor, que amarga as desventuras da periferia das grandes cidades brasileiras, mas que segue heroicamente lutando em busca da felicidade. Aproveitando elementos da saga de Cristo, Renato Russo conta a história de milhares de heróis anônimos da sociedade brasileira contemporânea.

J. Henderson (1964, p. ) observa que o mito do herói é o mais comum em todo o mundo, encontrado em todas as mitologias e épocas, persistindo na atualidade. Esse mito tem um poder de sedução dramático e uma importância psicológica profunda. As histórias dos heróis variam em detalhes e se modificaram muito na época moderna, mas todas guardam uma estrutura semelhante de nascimento humilde, lançamento em uma aventura, demonstração de sua força e falibilidade ante as tentações, seus triunfos e declínios.

Em "Faroeste Caboclo", não há um final feliz. Em seu lugar, há projeção de sofrimento e dor, mas fica uma mensagem de perseverança, de necessidade de busca infindável. O protagonista parece ser uma mescla confusa do herói-órfão abandonado e inseguro com o herói-martir deprimido, do herói-nômade que foge e busca com o herói-guerreiro, que tem agressividade e coragem para enfrentar os desafios e provas de sua jornada. Resulta um anti-herói brasileiro contemporâneo, urbano e contraditório, que projeta sobre os ouvintes da história diversas dualidades catárticas e simbólicas.

\section{Conclusões}

A análise permite concluir que o ciclo do herói é recontado com variantes em um produto da indústria cultural com bastante fidelidade ao percurso dos heróis das fábulas estudadas por V. Propp e por J. Campbell. João de Santo Cristo, herói/anti-herói de Renato Russo, persegue uma aventura contraditória entre tentações até os limiares que o levam ao desconhecido. Ultrapassa os limiares, o que constitui uma forma de autoaniquilação, conforme Campbell. Mas ultrapassa para dentro, como todo herói, para o "ventre da baleia" e experimenta várias metamorfoses. Essa é a fase favorita do mito-aventura, conforme Campbell, que se reconta em "Faroeste Caboclo". A canção popular, ao contrário do que advoga Benjamin, recorre e reinventa a memória e a tradição. Como observa Santiago (1989, p. 40), semelhante a um repórter, o narrador pós-moderno narra a ação enquanto espetáculo a que assiste, vê, observa; transmite 
uma sabedoria que decorre desta observação porque "sabe que o real e o autêntico são construções da linguagem".

Alegoricamente, observa Campbell, o mergulho da personagem denota a concentração e a renovação da vida. A lógica dos heróis, suas inquietações, buscas, quedas e triunfos fascinam, mesmo na indústria cultural, porque continuam permitindo aos homens reviver catarticamente in illo tempore as aventuras humanas: "falam com eloquência não da sociedade e da psique atuais, em estado de desintegração, mas da fonte inesgotável por intermédio da qual a sociedade renasce". (Campbell, 1997, 28) ${ }^{10}$. Daí resulta o prazer e a fruição da arte contemporânea, ainda que fragmentada e perturbada como a sua comercialização.

Hoje, porém, como observa Campbell, a teia do mito caiu, a tradição se abalou com a plena consciência do homem sobre sua existência. No passado todo sentido residia no grupo, hoje não há nenhum sentido no mundo, tudo está no indivíduo. O centro do reino do mistério e do perigo sofreu um deslocamento. As ciências e as religiões se dessacralizaram e desceram do céu à terra, mudando o ponto focal do milagre humano. Já não se sabe bem o que move as pessoas nem para onde elas caminham.

J. B. Thompson reconhece que as tradições perderam sua força na sociedade moderna e separaram-se da interação social compartilhada. Mas as práticas tradicionais não desapareceram, mudaram seu status. Elas perderam o monopólio da verdade inquestionável. Mas permanecem como um meio de dar sentido ao mundo (aspecto hermenêutico) e de criar sentidos de pertença. Ligaram-se a formas simbólicas mediadas, foram reimplantadas em contextos práticos da vida cotidiana, reincorporadas a novos contextos e reancoradas em novos tipos de unidades territoriais. As tradições mediadas, conclui, "não são menos autênticas que as transmitidas exclusivamente através de interações face a face." (Thompson, 1998, p. 178). É o que parece acontecer com a narrativa musical que analisamos.

A interpretação da narrativa de Renato Russo me leva a concordar com Thompson. Produto da indústria cultural, apresentada em shows massivos de rock and roll na década de 1980, empacotada em CDs negociados em lojas comerciais, a música "Faroeste Caboclo" ajudou a vender milhares de discos da banda Legião Urbana. Esse lado comercial não eliminou a

\footnotetext{
${ }^{10}$ Campbell observa que vivemos hoje os perigos psicológicos menos amparados do que as gerações passadas, mitológica e religiosamente orientadas. Enfrentamos sozinhos, como indivíduos "esclarecidos” e racionais, todos os deuses e demônios. "Não obstante”, diz ele, "ainda podemos ver, na multiplicidade de mitos e lendas que chegaram até nós o esboço de alguns elementos do nosso destino ainda humano. Para viver as experiências precisamos, porém, submeter-nos de certo modo à purgação e à entrega.” (Campbell, 1997, p. 107).
} 
potência simbólica e autêntica da narrativa como forma de representação da vida. Ela ganha força reimplantada na saga de milhares de heróis e anti-heróis anônimos brasileiros. Mesmo quando degradados, os mitos respondem a uma necessidade de criação da psique humana, como nos relembra M. Eliade (1991, p. 13): “Os símbolos jamais desapareceram da atualidade psíquica: eles podem mudar de aspecto; sua função permanece a mesma. Temos apenas de levantar suas novas máscaras".

\section{Anexo}

1. Não tinha medo o tal João de Santo Cristo

2. Era o que todos diziam quando ele se perdeu

3. Deixou pra trás todo o marasmo da fazenda

4. Só pra sentir no seu sangue o ódio que Jesus lhe deu

5. Quando criança só pensava em ser bandido

6. Ainda mais quando com tiro de soldado o pai morreu

7. Era o terror da cercania onde morava

8. E na escola até o professor com ele aprendeu

9. Ia pra igreja só prá roubar o dinheiro

10. Que as velhinhas colocavam na caixinha do altar

11. Sentia mesmo que era mesmo diferente

12. Sentia que aquilo ali não era o seu lugar

13. Ele queria sair para ver o mar

14. E as coisas que ele via na televisão

15. Juntou dinheiro para poder viajar

16. E de escolha própria escolheu a solidão

17. Comia todas as menininhas da cidade

18. De tanto brincar de médico aos doze era professor

19. Aos quinze foi mandado pro reformatório

20. Onde aumentou seu ódio diante de tanto terror

21. Não entendia como a vida funcionava

22. Descriminação por causa da sua classe e sua cor

23. Ficou cansado de tentar achar resposta

24. E comprou uma passagem foi direto a Salvador

25. E lá chegando foi tomar um cafezinho

26. E encontrou um boiadeiro com quem foi falar

27. E o boiadeiro tinha uma passagem

28. Ia perder a viagem mas João foi lhe salvar:

29. Dizia ele - Estou indo pra Brasília

30. Nesse país lugar melhor não há

31. Tô precisando visitar a minha filha

32. Eu fico aqui e você vai no meu lugar 
33. E João aceitou sua proposta

34. E num ônibus entrou no Planalto Central

35. Ele ficou bestificado com a cidade

36. Saindo da rodoviária viu as luzes de natal

37. - Meu Deus mas que cidade linda!

38. No Ano Novo eu começo a trabalhar

39. Cortar madeira aprendiz de carpinteiro

40. Ganhava mais de TRÊS mil por mês em Taguatinga

41. Na sexta feira ia pra zona da cidade

42. Gastar todo o seu dinheiro de rapaz trabalhador

43. E conhecia muita gente interessante

44. Até um neto bastardo do seu bisavô

45. Um peruano que vivia na Bolívia

46. E muitas coisas trazia de lá

47. Seu nome era Pablo e ele dizia

48. Que um negócio ele ia começar

49. E Santo Cristo até a morte trabalhava

50. Mas o dinheiro não dava pra ele se alimentar

51. E ouvia às sete horas o noticiário

52. Que sempre dizia que o seu ministro ia ajudar

53. Mas ele não queria mais conversa

54. E decidiu que como Pablo ele ia se virar

55. Elaborou mais uma vez seu plano santo

56. E sem ser crucificado a plantação foi começar

57. Logo, logo os maluco da cidade

58. Souberam da novidade

59. - Tem bagulho bom ai!

60. E João de Santo Cristo ficou rico

61. E acabou com todos os traficantes dali

62. Fez amigos, frequentava a Asa Norte

63. Ia prá festa de Rock prá se libertar

64. Mas de repente

65. Sob uma má influência dos boyzinho da cidade

66. Começou a roubar

67. Já no primeiro roubo ele dançou

68. E pro inferno ele foi pela primeira vez

69. Violência e estupro no seu corpo

70. - Vocês vão ver, eu vou pegar vocês!

71. Agora Santo Cristo era bandido

72. Destemido e temido no Distrito Federal

73. Não tinha nenhum medo de polícia

74. Capitão ou traficante de Playboy ou general 
75. Foi quando conheceu uma menina

76. E de todos os seus pecados ele se arrependeu

77. Maria Lúcia era uma menina linda

78. E o coração dele prá ela o Santo Cristo prometeu

79. Ele dizia que queria se casar

80. E carpinteiro ele voltou a ser

81. - Maria Lúcia eu pra sempre vou te amar

82. E um filho com você eu quero ter

83. O tempo passa

84. E um dia vem na porta um senhor de alta classe com dinheiro na mão

85. E ele faz uma proposta indegorosa

86. E diz que espera uma resposta, uma resposta do João

87. - Não boto bomba em banca de jornal

88. E nem em colégio de criança

89. Isso eu não faço não

90. E não protejo general de dez estrelas

91. Que fica atrás da mesa com o cú na mão

92. E é melhor o senhor sair da minha casa

93. Nunca brinque com um peixe de ascendente escorpião

94. Mas antes de sair, com ódio no olhar

95. O velho disse:

96. - Você perdeu a sua vida, meu irmão!

97. - Você perdeu a sua vida, meu irmão!

98. - Você perdeu a sua vida, meu irmão!

99. Essas palavras vão entrar no coração!

100. - Eu vou sofrer as consequências como um cão.

101. Não é que o Santo Cristo estava certo

102. Seu futro era incerto

103. E ele não foi trabalhar

104. Se embedou e no meio da bebedeira

105. Descobriu que tinha outro trabalhando em seu lugar

106. Falou com Pablo que queria um parceiro

107. Também tinha dinheiro e queria se armar

108. Pablo trazia o contrabando da Bolívia

109. E Santo Cristo revendia em Planaltina

110. Mas acontece que um tal de Jeremias

111. Traficante de renome apareceu por lá

112. Ficou sabendo dos planos de Santo Cristo

113. E decidiu que com João ele ia acabar.

114. Mas Pablo trouxe uma Winchester

115. E Santo Cristo já sabia atirar

116. E decidiu usar a arma só depois 
117. Que Jeremias começasse a brigar

118. Jeremias maconheiro sem vergonha

119. Organizou a Roconha e fez todo mundo dançar

120. Desvirginava mocinhas inocentes

121. E dizia que era crente mas não sabia rezar

122. E Santo Cristo há muito não ia pra casa

123. E a saudade começou a apertar

124. - Eu vou me embora, eu vou ver Maria Lúcia

125. Já tá em tempo de a gente se casar

126. Chegando em casa então ele chorou

127. E pro inferno ele foi pela segunda vez

128. Com Maria Lúcia Jeremias se casou

129. E um filho nela ele fez

130. Santo Cristo era só ódio pro dentro

131. E então o Jeremias prum duelo ele chamou

132. - Amanhã, as duas horas na Ceilândia

133. Em frente ao lote 14 que é pra lá que eu vou

134. E você pode escolher as suas armas

135. Que eu acabo com você, seu porco traidor

136. E mato também Maria Lúcia

137. Aquela menina falsa pra quem jurei o meu amor

138. E Santo Cristo não sabia o que fazer

139. Quando viu o repórter da televisão

140. Que deu notícia do duelo na TV

141. Dizendo a hora o local e a razão

142. No sábado, então as duas horas

143. Todo o povo sem demora

144. Foi lá só pra assistir

145. Um homem que atirava pelas costas

146. E acertou o Santo Cristo

147. Começou a sorrir

148. Sentindo o sangue na garganta

149. João olhou pras bandeirinhas

150. E o povo a aplaudir

151. E olhou pro sorveteiro

152. E pras câmeras e agentes da TV que filmava tudo ali

153. E se lembrou de quando era uma criança

154. E de tudo o que viveu até ali

155. E decidiu entrar de vez naquela dança

156. - Se via-cruis virou circo, estou aqui.

157. E nisso o sol cegou seus olhos

158. E então Maria Lúcia ele reconheceu 
159. Ela trazia a Winchester 22

160. A arma que seu primo Pablo lhe deu

161. - Jeremias, eu sou homem. Coisa que você não é

162. E não atiro pelas costas, não.

163. Olha pra cá filha da puta sem vergonha

164. Dá uma olhada no meu sangue

165. E vem sentir o teu perdão

166. E Santo Cristo com a Winchester 22

167. Deu cinco tiros no bandido traidor

168. Maria Lúcia se arrependeu depois

169. E morreu junto com João, seu protetor

170. O povo declarava que João de Santo Cristo

171. Era santo porque sabia morrer

172. E a alta burgesia da cidade não acreditou na história

173. Que eles viram da TV

174. E João não conseguiu o que queria

175. Quando veio pra Brasília com o diabo ter

\section{Referências bibliográficas}

BARTHES, Roland (1971). Análise estrutural da narrativa. Petrópolis: Vozes. BENJAMIN, Walter (2001). "El narrador". In: Para una crítica de la violencia. Madrid: Taurus.

BREMOND, Claude (1971). "A lógica dos possíveis narrativos". In: BARTHES, Roland. Análise estrutural da narrativa. Petrópolis: Vozes.

CAMPBELL, Joseph (1997). O herói de mil faces. São Paulo: Cultrix/Pensamento.

CAMPOS, Haroldo de (1973). Morfologia do Macunaíma. São Paulo: Perspectiva.

ELIADE, Mircea (1991). Imagens e símbolos. São Paulo: Martins Fontes.

HANDERSON, Joseph L. (1964). “Os mitos antigos e o homem moderno”. In: JUNG, C. G. O homem e seus símbolos. Rio de Janeiro: Nova Fronteira.

JUNG, Carl G. (2000). Arquétipos e o inconsciente coletivo. Petrópolis: Vozes.

LUSVARGHI, Luiza (2005). “O realismo e o popular no cinema nacional da pós-modernidade". Libero. n. 15, Ano 8, v. 1.

MOTTA, Luiz G. (2005). Narratologia. Brasília: Casa das Musas.

PROPP, Vladimir I. (1984). Morfologia do conto maravilhoso. Rio de Janeiro: Forense.

REIS, C. e LOPES, A. C. M. (1988). Dicionário de teoria da narrativa. São Paulo: Ática. 
RICOEUR, Paul (1994). Tempo e narrativa. São Paulo: Papirus.

SANTIAGO, Silviano (1989). Nas malhas da letra. São Paulo: Cia. das Letras.

THOMPSON, John B. (1998). Mídia e modernidade. Petrópolis: Vozes.

TODOROV, Tzvetan (1970). As estruturas narrativas. São Paulo: Perspectiva.

Recebido em setembro de 2010.

Aprovado em julho de 2011.

resumolabstract

A narrativa mediada e a permanência da tradição: percurso de um anti-herói brasileiro

Luiz Gonzaga Motta

O artigo relata um exercício de análise da narrativa da musica "Faroeste caboclo", composição de Renato Russo. O exercício aplica livremente os procedimentos propostos pelo narratólogo russo Vladimir Propp em um produto típico da indústria cultural para compreender a narrativa de um anti-herói brasileiro contemporâneo. O primeiro objetivo é observar se a proposta de Propp ainda é válida como processo básico de interpretação semântica de um produto da indústria cultural (de natureza comercial, diferente dos contos infantis nos quais o autor russo se baseou). Um segundo objetivo, mais denso, verifica se essa narrativa mediada guarda alguma identidade com o ciclo universal do herói e a natureza simbólica das narrativas tradicionais. Conclui que as narrativas mediadas não são menos autênticas: estão apenas ancoradas em novos suportes de comunicação. Permanecem como autênticos modelos dramáticos de experiência e de representação da vida.

Palavras-chave: análise da narrativa, funções narrativas, sequência narrativa, anti-herói, interpretação semântica

The mediated narrative and the permanence of the tradition: a course of a Brazilian anti-hero

Luiz Gonzaga Motta

The article describes a narrative analysis of the song "Faroeste Caboclo", written by the Brazilian composer Renato Russo. It freely applies the procedures proposed by the Russian narratologist Vladimir Propp in a typical product of the cultural industry to comprehend the narrative of a Brazilian modern anti-hero. The first objective is to observe whether Propp proposals are still valid as procedures for semantic interpretation of a product of the cultural industry (which retain a commercial nature, different from children's tales in which the Russian author based his procedures). The second objetive tests whether the mediated narrative still keeps an identity with the universal cycle of the hero and the symbolic nature of traditional narratives. The article concludes that mediated narratives are not less authentic: they have been reincorporated into new contexts and re-anchored in 


\section{Luiz Gonzaga Motta}

new communication supports. They still retain, however, the authentic dramatic models to represent human life.

Key words: narrative analysis, narrative functions, narrative sequence, hero, semantic interpretation

Luiz Gonzaga Motta - "A narrativa mediada e a permanência da tradição: percurso de um anti-herói brasileiro". Estudos de Literatura Brasileira Contemporânea, n. 38. Brasília, julho-dezembro de 2011, p. 185-212.

212 estudos de literatura brasileira contemporânea, n.38, jul./dez. 2011, p. 185-212 